\title{
Study of Utilisation of Hypo Sludge in High Performance Concrete
}

\author{
Abhinandan Singh Gill* \\ *Final year B.Tech student in Civil Engineering, Guru Nanak Dev Engineering College, Ludhiana-Punjab-India
}

\begin{abstract}
Population scenario came towards India by means of increasing industries. More than 200 million tonnes of agriculture and industrial waste is produced every year .Hypo sludge produced by mills is posing major economic and environmental problem .The main recycling and disposal routes for paper sludge includes land spreading over croplands and disposal into farmlands or to landfills which gives rise to contamination of soil. Since energy plays a crucial role in growth of developing countries like India and with low availability of non-renewable energy resources linked with the requirement of large quantities of energy for building materials like cement the re-use of by products or wastes produced in nay industrial process is a high priority today and one way of recycling these materials is to seek concrete applications with compatible use and the same characteristics. The published work shows that paper industry is one of the better sectors to get environmental objectives since raw materials are renewable, its products and wastes are recyclable and production processes are capable of technological improvements to protect the environment.
\end{abstract}

The paper presents the overview of published work on utilisation of hypo sludge with high performance concrete, exploring its pozzolanic properties, mechanical properties like compressive strength, splitting strength, modulus of elasticity, water absorption test, sorptivity and cost analysis are presented.

Keywords -M40 concrete, hypo sludge, pozzolanic properties, mechanical properties, durability, and cost.

\section{I.INTRODUCTION}

Energy is a backbone of developing countries like India, Pakistan, Bahrain and most of Asian countries. Industrialisation with rapid urbanisation to improve the standard of living is increasing the need of energy in these countries. Further the increasing population has caused large demand shortage of building material and the idea of using hypo sludge shall not only provide resources for construction but will also solve the problem of waste management. The re-use of waste is really crucial as it not only decrease the pollution and prevent green house effect but also helps in saving energy in production process by recycling. During the cement production green house gases such as $\mathrm{CO}_{2}$ is emitted in the atmosphere which acts as a silent killer. About 1 million ton of green house gases are emitted during the production of 4 million tonnes of cement [1]. Using papers sludge waste as a replacement to cement reduces the degradation of environment and ozone layer to much larger extent. For each tone of recycled paper about $300 \mathrm{~kg}$ of paper waste sludge is produced [2] which is comparatively a large volume of sludge produced each day. 11 million tonnes of waste is produces every year by paper and pulp sector in Europe [3]. The use of hypo sludge provides a way to greener technology as the presence of sulphate is $0.57 \%$ of the total weight moreover the emission of carbon dioxide and sulphur dioxide that acts as a silent killer in the environment is reduced since less productivity is involved. Waste and industrial byproducts such as paper mill sludge can help to develop a profitable material by blending different proportions of paper waste sludge with cement.

\section{II.THE POZZOLANIC PROPERTIES OF PAPER SLUDGE WASTE}

Investigation was carried out to determine the pozzolanic properties by establishing optimal conditions for transforming paper de-inking sludge into pozzolanic [4]. They dry hypo sludge was burnt in an electric laboratory furnace from $600^{\circ} \mathrm{C}$ to $800^{\circ} \mathrm{C}$ for 2 and 5 hours. The resulting products were grounded and sieved to a particle size of under $45 \mu \mathrm{m}$. The mineralogical composition by Xray diffraction was detected where XRD patterns were accomplished in SIEMENS D-5000 diffractometer using a wolfram cathode and copper plate as anode. The semi-quantitative mineralogical components were accomplished using the method of the reflectant powders and compared with results from conventional mathematical program the areas of peaks where each mineral as quantified were determined through the Gaussian adjustment and subtraction of the base line.

To observe and compare the pozzolanic activity of calcined sludge commercial metakaolin was used as a reference. An accelerated method by using saturated lime solution at $40^{\circ} \mathrm{C}$ for $1,7,28,90$ days was used. $\mathrm{CaO}$ concentration in the solution was analysed at the end of each period [5]. The combined lime $(\mathrm{mmol} / \mathrm{L})$ was obtained by the difference between the concentration in the control saturated lime solution and $\mathrm{CaO}$ present in the solution in contact with the sample. The analysis indicates that dry industrial waste is formed mainly of calcium oxide, silicates and alumina. The presence of chloride ions $(0.04 \%)$ and loss on ignition $(47.62 \%)$ was detected. 
The starting sludge had an organic matter content of $29 \%$. The mineral fraction of the dry sludge mainly consists of kaolinite $(21 \%)$, calcite $(35 \%)$ and other minerals such as phyllosilicates type chlorite and micas $(11 \%)$, talc $(2 \%)$ and quartz $(2 \%)$ are also present in small amounts.

Table 1: Chemical composition of the raw sludge (\% by mass)

\begin{tabular}{|c|c|c|c|c|c|c|c|c|c|c|c|}
\hline $\begin{array}{c}\text { Oxi } \\
\text { de } \\
(\%)\end{array}$ & $\begin{array}{c}\mathrm{SiO} \\
\mathrm{Al}_{2}\end{array}$ & $\mathrm{O}_{3}$ & $\begin{array}{c}\mathrm{F}_{2} \\
\mathrm{O}_{3}\end{array}$ & $\begin{array}{c}\mathrm{Ca} \\
\mathrm{O}\end{array}$ & $\begin{array}{c}\mathrm{Mg} \\
\mathrm{O}\end{array}$ & $\begin{array}{c}\mathrm{Ti} \\
\mathrm{O}_{2}\end{array}$ & $\begin{array}{c}\mathrm{K}_{2} \\
\mathrm{O}\end{array}$ & $\begin{array}{c}\mathrm{P}_{2} \\
\mathrm{O}_{5}\end{array}$ & $\begin{array}{c}\mathrm{SO} \\
3\end{array}$ & $\begin{array}{c}\mathrm{Na}_{2} \\
\mathrm{O}\end{array}$ & $\mathrm{LOI}$ \\
\hline $\begin{array}{c}\text { Raw } \\
\text { slud } \\
\text { ge }\end{array}$ & $\begin{array}{c}18 . \\
01\end{array}$ & $\begin{array}{c}10.1 \\
4\end{array}$ & 0.55 & 19. & 2.5 & 0.2 & 0.2 & 0.1 & 0.3 & 0.2 & 47. \\
8 & 6 & 1 & & 3 & 5 & 62 \\
\hline
\end{tabular}

\section{MECHANICAL PROPERTIES}

\section{A. Compressive Strength}

The compressive strength of concrete by replacing hypo sludge [6] accordingly in the range of 10 to $40 \%$ in the specified design mix was examined. The compressive strength was determined at 7, 14, 28 days of M40 by using compression testing machine of capacity 200MT. They found out that with 10 percent addition of hypo sludge in reference sample, percent decrease of 46.79 at $7^{\text {th }}$ day was observed following 51.95 at $14^{\text {th }}$ day and 50.28 at $28^{\text {th }}$ day, with increase in proportion of paper waste sludge in cement the compressive strength reduced further.

\section{B. Split Tensile Strength}

The research data demonstrated the split tensile strength test to investigate the average split strength [6]. The split strength was $9.34 \%$ less than the reference sample when $10 \%$ of hypo sludge was added at 56 days. The average split strength kept on reducing from 3.96 to 1.33 with percentage increase of paper waste sludge to $40 \%$. This signifies that with increased percentage of hypo sludge, split tensile strength decreased.

\section{Modulus of Elasticity}

Deflection of concrete slabs and beams is common structural movement. Dead and live loads develops flexural strains which results in deflection. This may also occur in cracking in tensile zone. Modulus of elasticity of concrete is of prime importance to determine the deflection of structural elements.

The modulus of elasticity can be calculated by difference of the measured stresses and strains on an upper level (i.e.1/3 of the value of compressive strength) and a lower level (i.e.0.5 N/mm2). With respect to reference specimen there was $10.71 \%$ decrement in modulus of elasticity at 56 days [7] and with $10 \%$ addition of hypo sludge as supplementary cementious material the modulus of elasticity was equivalent to $16667 \mathrm{Mpa}$. The Modulus of elasticity (MPa) drop-off from $18667 \mathrm{MPa}$ (the reference specimen) to 12100 with percent increase in the content of paper waste sludge from $0 \%$ to $40 \%$ respectively.

The modulus of elasticity of concrete with partial replacement of cement by paper waste sludge and fly ash (thermal industry waste) in M40 concrete mix was evaluated [8]. It was found out that at $10 \%$ replacement with paper waste sludge and fly ash modulus of elasticity was same as of traditional concrete M40 and as the addition of hypo sludge and thermal industry waste increased the modulus of elasticity dropped by $12.14 \%$ to $16400 \mathrm{Mpa}$ from 18667Mpa.

Table 2: Results of Modulus of Elasticity and \% Change of Modulus of Elasticity at 56 days for M40 [8]

\begin{tabular}{|c|c|c|}
\hline Mix Type & $\begin{array}{c}\text { Modulus of } \\
\text { Elasticity (MPa) } \\
\text { after 56 days }\end{array}$ & $\begin{array}{c}\text { \% Change in } \\
\text { Modulus of } \\
\text { Elasticity at 56 } \\
\text { days }\end{array}$ \\
\hline A2-M40 & 18667 & 0 \\
\hline C5-M40 & 18667 & 0 \\
\hline C6-M40 & 16400 & $(-) 12.14$ \\
\hline C7-M40 & 14000 & $(-) 25.00$ \\
\hline C8-M40 & 12857 & $(-) 31.12$ \\
\hline
\end{tabular}

\section{Durability}

Concrete is a tough material with great strength. Being porous material it interacts with surrounding environment. The flow of gas and water determine the durability of concrete. The main characteristic influencing the durability of concrete is its permeability. Permeability is defined as a measure of flow of water under pressure which depends on the porous structure of concrete. In other words it indicates the mechanism that uptake and transport water and gaseous substances.

Sorptivity is used to measure the response of concrete to pressure. It is defined as the ability to absorb and transmit water through it by capillary suction. In other words the uptake of water by hardened, unsaturated concrete is characterised by sorptivity.

Table 3: Acceptance limits for durability indexes [9]

\begin{tabular}{|c|l|c|c|}
\hline \multicolumn{2}{|c|}{ Acceptance Criteria } & $\begin{array}{c}\text { OPI (log } \\
\text { scale) }\end{array}$ & $\begin{array}{c}\text { Sorptivity } \\
\text { (mm/h) }\end{array}$ \\
\hline \multicolumn{2}{|c|}{ Laboratory concrete } & $>10$ & $<6$ \\
\hline As-built & Full acceptance & $>9,4$ & $<9$ \\
\cline { 2 - 4 } Structures & Conditional & 9,0 to & 9 to 12 \\
& acceptance & 9,4 & \\
\cline { 2 - 4 } & Remedial & 8,75 to & 12 to 15 \\
& measures & 9,0 & \\
\cline { 2 - 4 } & Rejection & $<8,75$ & $>15$ \\
\hline
\end{tabular}

\section{a). Water Absorption Test}

The cylinder of $100 \mathrm{~mm}$ diameter $\mathrm{x} 50 \mathrm{~mm}$ height cylinder was immersed in water for 90 days curing [9]. For 24 hours the specimens were oven dried at the temperature $110^{\circ} \mathrm{C}$ until the mass became 
constant. The mass was weighed again. The weight W1 was referred as dry weight of the cylinder and W2 was given to wet weight of the cylinder which was obtained after keeping specimen in hot water at $85^{\circ} \mathrm{C}$ for 3.5 hours.

$\%$ water absorption $=[(W 2-W 1) \div W 1] \times 100$ Where,

$W 1=$ Oven dry weight of cylinder in grams $W 2=$ After 3.5 hours wet weight of cylinder in grams.

Based on the experiment it was found out that the water absorption of hypo sludge concrete shows lower rate of absorption at $10 \%$ replacement with paper waste sludge with M40 grade concrete corresponding to $1.53 \%$ which is a bit higher than traditional concrete at 90 days.

\section{b) Sorptivity}

It is measured as the rate of uptake of water. The action is composed of transport mechanism which depends on solid and fluid characteristics. Sorptivity is the function of pore structure (radius, continuity of capillary and tortuosity of porous sold and density, surface tension and viscosity of the liquid.

Water was used as the test fluid [9]. The cylinder specimen of size $100 \mathrm{~mm}$ dia $\times 50 \mathrm{~mm}$ height was drowned in water for 90 days curing. The level of water was not kept more than $5 \mathrm{~mm}$ above the base of specimen, a non-absorbent coasting was provided to seal to prevent the flow from the peripheral surface. The quantity of water absorbed was measured by weighing the specimen on a top pan balance weighting up to $0.1 \mathrm{mg}$ in time period of 30 minutes. Dampened tissues were used to wipe off the surface water on the specimen. The cumulative water absorption (per unit area of inflow surface) increases as the square root of elapsed time (t)

\section{$I=S . t_{2}^{1}$ Therefore $S=\frac{I}{t_{2}^{1}}$}

Where $\mathrm{S}=$ sorptivity in $\mathrm{mm}$. And $\mathrm{t}=$ elapsed time in mint.

$$
I=\Delta w \div A d
$$

$\Delta w=$ Change in weight $=W 2-W 1$

$\mathrm{A}=$ surface area of the specimen after 30minutes capillary suction of water in grams.

$\mathrm{D}=$ density

$\mathrm{W} 1=$ Oven dry weight of cylinder in grams

W2=Weight of cylinder after 30 minutes capillary suction of water in grams

The sorptivity was found to be $4.65 \mathrm{~mm} / \mathrm{min}^{0.5}$ at $10 \%$ addition of paper waste sludge with concrete and there after it showed the increasing trend with increased proportions of hypo sludge.

\section{IV.ECONOMIC FEASIBILITY}

The test points towards developing low cost concrete by varying mix proportions from $10 \%$ replacement to $40 \%$ replacement [6]. The cost of
Materials taken in the test was as followingCement (HATHI OPC 53 grade) - 6.40(Rs $/ \mathrm{kg})$, Hypo sludge-0.60(Rs/kg), Fine aggregates0.60(Rs/kg), Coarse aggregates (20mm Down) 0.65(Rs/kg), Grit-0.65 (Rs/kg).

The percentage decrease in cost was 7.18 with $10 \%$ addition of hypo sludge and the cost reduced further with increasing percentage of paper waste sludge in M40 concrete mix.

\section{V.CONCLUSION}

Based on limited experimental investigation concerning M40 grade concrete the following observations are made regarding the use of hypo sludge (paper industry waste) as supplementary cementitious material:

a) The calcined product obtained from paper waste sludge at optimal conditions of calcinations exhibits high pozzolanic property and permits its possible reuse as a pozzolanic material.

b) As hypo sludge percentage increase in M40 grade, compressive strength and split tensile strength decreases hence concrete mix with $5 \%$ to $10 \%$ of hypo sludge can be used for constructing temporary structures.

c) Modulus of elasticity decreases with increased percentage of hypo sludge and with $10 \%$ replacement with fly ash and hypo sludge the modulus of elasticity is same as that of M40 grade traditional concrete.

d) The hypo sludge concrete shows higher water absorption and sorptivity than traditional concrete.

$e$ ) The cost analysis indicates that with addition of paper waste sludge the cost of concrete decreases.

f) The environmental issues associated with disposal of solid waste and carbon dioxide emissions from production of Portland cement is reduced with the use of hypo sludge hence it gives a way for greener concrete.

g) Hypo sludge with pozzolanic addition can be used in M40 concrete but judicious decision is to be taken by engineer.

\section{References}

[1] Mr.R.Balamurugan and Mr.R.Karthickraja, "An Experimental Investigation of Partial replacement of Cement by Industrial Waste (Hypo Sludge)," International Journal of Engineering Research and Applications, vol. 4, no. 1, April 2014, pp. 430-435.

[2] R. Srinivasan and M. Palanisamy, "Experimental Investigation In developing Low Cost Concrete From Paper Industry Waste,” M. Engg. Thesis report, Department of Civil Engineering, Tamilnadu College of Engineering, Karumatham patti, Coimbatore-641659, Tamilnadu, India.

[3] S.F.Seyyedalipour, D.Y.Kebria, N.RMalidarreh and G.Norouzneja, "Study of Utilization of Pulp and Paper Industry Wastes in Production of Concrete," International Journal of Engineering 
Research and Applications, vol. 4, pp. 115-122,

2014.

[4] R. Garcia, R. Vigil de la Villa, I. Vegas , M. Fras and M. I. Sanchez de Rojas, "The pozzolanic properties of paper sludge waste," Construction Building Material , vol. 22, pp. 1484-90, 2008.

[5] M. Frias, MI. Sanchez de Rojas and J. Rivera, "Influence of calcining conditions on pozzolanic activity and reaction kinetics in paper sludgecalcium hydroxide mixes," Proceedings of the 8 CANMET/ ACI international conference on fly ash, silica fume, slag and natural pozzolans in concrete, Las Vegas, pp. 879-86, 2004,

[6] J. pitroda, L. B. Zala and F. S. Umrigar, "Innovative Use of Paper Industry Waste (Hypo sludge) in design mix concrete." International Journal of Advanced Engineering Technology, vol. 4, no. 1, Jan-March 2013

[7] J. V. Solanki and J. Pitroda, "Study of Modulus of Elasticity of concrete with Partial Replacement of Cement by Hypo Sludge Waste from Paper industry," Global Researc Analysis, vol. 2, no. 1, Jan. 2013.

[8] J. R. Pitroda, F. S. Umrigar, "Evaluation of Modulus of Elasticity of Concrete with Partial Replacement of Cement by Thermal Industry Waste (Fly Ash) and Paper Industry Waste (Hypo Sludge)," International Journal of Engineering Science and Innovative Technology, vol. 2, no. 1, Jan. 2013.

[9] J. Pitroda, L.B. Zala, F. S. Umrigar, "Durability of concrete with Partial Replacement of Cement by Paper Industry Waste (Hypo Sludge)," International Journal of Innovative Technology and Exploring Engineering, vol. 2, no. 3, Feb. 2013. 